\title{
ANALISIS KEBEBASAN BERPENDAPAT TERHADAP AGAMA \\ MENURUT PASAL 156A KUHP (STUDI KASUS PUTUSAN NOMOR 784/PID/2018/PT.MDN).
}

\author{
Livianto Sanjaya \\ (Mahasiswa Program S1 Fakultas Hukum Universitas Tarumanagara) \\ (E-mail: livianto01@gmail.com)
}

Dr. Firman Wijaya, S.H., M.H.

(Corresponding Author)

(Dosen Fakultas Hukum Universitas Tarumanagara, Meraih Sarjana Hukum pada Fakultas Hukum Universitas Tarumanagara, Magister Hukum pada Fakultas Hukum Universitas 17 Agustus 1945 Jakarta,

Doktor (Dr.) pada Fakultas Hukum Universitas Krisnadwipayana)

(E-mail: era.hukum.mahasiswa@fh.untar.ac.id)

\begin{abstract}
Meliana was charged with violating Article 156 a of the Indonesian Criminal Code and was sentenced by a Medan District Court judge with 18 months in prison for being considered a religious blasphemy for complaining about the volume of the call to prayer near her home. The problem is how freedom of expression relates to religion according to Article 156a of the Criminal Code. The research method used in writing this thesis is normative legal research. The results showed that the Medan District Court Judge considered that the element of "blasphemy" was fulfilled by the fact that based on the conversation delivered by witnesses at the trial and there was a very real relationship between the complaints of the defendant and the anger of Muslims and the Fatwa of the Indonesian Ulema Council of North Sumatra Province stated that The defendant is blasphemous towards Islam, which is the religion of Islam adopted in the State of Indonesia. Freedom of opinion is not free freedom, but freedom that is limited by applicable regulations (Law). This case shows that the blasphemy law is actually a tool of conflict, not a conflict prevention as the government considers it. If this law is not abolished, then there must be a way for the law to "no longer be used." Law enforcement officials truly understand the essence of the blasphemy law, so as not to set a bad precedent in the midst of national pluralism.
\end{abstract}

Keywords: Opinion Freedom, Article 156a.

\section{PENDAHULUAN}

\section{A. Latar Belakang}

Indonesia memproklamirkan kemerdekaannya pada tanggal 17 Agustus Tahun 1945, dan saat ini usia Indonesia setelah merdeka adalah \pm 74 tahun, di mana banyak pembaharuan terjadi, tak terkecuali pembaharuan di bidang hukum. Dalam sudut pandang ini, setelah kemerdekaan, perombakan terjadi dan mampu mengubah masyarakat yang awalnya terbelenggu menjadi merdeka, begitu juga dalam 
perlindungan hukum bagi warganegaranya, telah mengalami banyak perubahan tak terkecuali perlindungan atas hak asasi manusia (HAM).

HAM mempersepsikan kebebasan dalam suatu kerangka hukum yang diberikan Negara, dan Jock Locke sendiri membuat hipotesa dalam kaitannya dengan hak individu sebagai pribadi kodrati, yang ia peroleh manusia sejak lahir. ${ }^{1}$ Kebebasan yang dimaksud adalah kebebasan menyampaikan pendapat atau menyampaikan unek-unek dalam pikirannya tanpa memandang, ras, suku dan agama.

Kebebasan menyampaikan pendapat lahir dari suatu pemikiran dan unek-unek pribadi individu dan ini merupakan suatu pengejawantahan diri manusia seiring dengan peradaban manusia saat ini. Kebebasan berpendapat merupakan hal penting dan krusial dalam era demokrasi saat ini, dalam artian kebebasan yang tidak sebebas-bebasnya, di mana masih aturan aturan etika, norma dan budaya. Hak asasi manusia diakui oleh dunia, sehingga pada dasarnya Perserikatan Bangsa-Bangsa menghasilkan piagam penting akan lahirnya sebuah deklarasi Universal HAM. $^{2}$

Kebebasan menyampaikan pendapat juga harus diungkapkan secara hati-hati tanpa menyinggung orang atau pihak lain, sehingga hal tersebut tidak menimbulkan misinterpretasi makna dan arti dari suatu pengungkapan kebebasan berpendapat, seperti penistaan atau penodaan agama. Kasus penistaan agama terjadi karena perbedaan falsafah, dan pemahaman terhadap ajaran yang dianut masyarakat, sehingga orang dipandang menistakan atau menodai agama dengan ucapan yang sarkasme, atau ucapan yang menyinggung perasaan umat beragama lain.

Kasus penoadaan agama pada dasarnya sulit dibuktikan di sidang pengadilan, dan majelis hakim banyak mendapat intervensi dari pihak lain yang berseberangan atau yang memiliki kepahaman lain dalam agama, sehingga mereka emosi dan mampu menggerakkan masyarakat

${ }^{1}$ El Muhtaj Majda, Hak Asasi Manusia dalam Konstitusi Indonesia, (Jakarta: Kencana, 2007), hal. 29.

${ }^{2}$ Miriam Budiardjo, Dasar-dasar Ilmu Politik, (Jakarta: PT. Gramedia, 2008), hal. 211. 
untuk melakukan intervensi di dalamnya. Hal ini bisa terjadi di sidang pengadilan dengan menghakimi secara hukum atau main hakim sendiri, sehingga pelaku diproses secara hukum, namun ada aspek lain terkait dengan pendirian hakim dalam menyidangkan perkara penodaan atau penistaan agama. Keyakinan hakim adalah salah satu hal penting dalam memutus suatu perkara di pengadilan.

Aspek penegakan hukum terkait kasus penistaan atau penodaan agama harus mampu mewujudkan kepastian hukum yang hakiki, dalam artian bahwa perbuatan apa yang boleh dilakukan atau yang tidak boleh dilakukan, tindakan atau kewenangan pemerintah dalam melaksanakan penegakan hukum terkait kasus penodaan agama, keamanan dalam penegakan hukum tentunya harus melibatkan Negara atau individu di dalamnya. $^{3}$

Kasus penistaan agama di Indonesia yang telah diproses dan diadili melalui pengadilan, baik pengadilan tingkat pertama, banding dan kasasi sudah banyak sekali diantaranya adalah kasus wartawan Arswendo Atmowiloto di tahun 1990, Lia Eden di tahun 1998, Ahmad Mussadeq di tahun 2016, Kasus Tajul Muluk alias Haji Ali Murtadho Pemimpin syiah di Kab. Sampang, Jawa Timur di tahun 2012 dan Gubernur DKI Jakarta Basuki Tjahatja Purnama (Ahok) dan para tersangka kasus penistaan agama yang divonis dengan dakwaan melakukan pelanggaran terhadap Pasal 156a KUHP.

Pasal 156a KUHP adalah sebuah pasal sisipan, setelah adanya kodifikasi sebagai bagian resmi dari hukum positif setelah era kemerdekaan. Pasal 156a KUHP berasal dari Penetapan Presiden Nomor 1/PNPS Tahun 1965 tentang Pencegahan dan Penyalahgunaan dan/atau Penodaan Agama. ${ }^{4}$

${ }^{3}$ Peter Mahmud Marzuki, Pengantar Ilmu Hukum, Cetakan Keempat, (Jakarta: Kencana Prenada Media Grup, 2012), hal. 137.

${ }^{4}$ Shidarta, "Bahaya Tafsir A-Historis Terhadap Pasal 156a KUHP", https://businesslaw.binus.ac.id/2018/07/10/bahaya-tafsir-a-historis-terhadap-pasal-156a-kuhp/, $\quad$ diakses $\quad 20$ September 2019. 
Pasal 156a memiliki sebutan sebagai pasal penistaan atau penodaan agama yang masuk dalam kategori delik agama. Pasal 156a KUHP dijadikan rujukan hakim dalam memutus suatu perkara penodaan agama. Dan selama ini bisa dijadikan dasar, di mana pelaku penodaan atau penistaan agama umumnya dihukum dengan pidana penjara 5 tahun. ${ }^{5}$

Tujaun dari pemberian hukum atau pemidanaan atau juga sanksi pidana pada dasarnya adalah mencari kebenaran materil, terutama dalam menerapkan ketentuan hukum acara pidana secara jujur, sistematis dan terarah terkait dengan pelanggaran hukum yang dilakukan oleh pelaku penistaan atau penodaan agama. Pasal 184 ayat (1) KUHAP dijadikan alat bukti yang sah dan bisa membantu hakim dalam mengambil keputusan guna penangahan masalah terkait dengan aspek pembuktian, seperti keterangan terdakwa, keterangan saksi, adanya surat, petunjuk dan keterangan ahli tentunya. ${ }^{6}$

Guna menentukan bahwa seseorang bisa dijatuhi hukum, dalam aturan KUHAP adalah sekurang-kurangnya dua alat bukti yang sah dan hakim yakin bahwa tindakan pelaku memenuhi unsur yang didakwakan dalam pasarl tersebut.

Penelitian ini menarik, karena dalam penulisan skripsi ini Penulis akan mengkaji tentang tindak pidana penistaan agama yaitu kasus Meiliana terjadi pada akhir Juli 2016 yang berawal dari permintaan untuk mengecilkan volume suara adzan di dekat rumahnya di Tanjungbalai. Permintaan itu ditanggapi dengan beragam emosi, yang menyulut terjadinya kerusuhan, dan sejumlah orang merusak rumah Meliana dan vihara-vihara di wilayah Tanjungbalai, dan ujung-ujungnya Majelis Ulama Indonesia (MUI) Sumatera Utara mengeluarkan fatwa konkrit, dan MUI mengharapkan kasus Meliana diproses secara hukum karena

5 Afriandi MS, “Analisis Hukum Pidana Terhadap Tindak Pidana Penistaan Agama di Aceh”, Jurnal Penelitian Hukum DE JURE, ISSN 1410-5632 Vol. 17 No. 1, Maret 2017: 1- 12, hlm. 3.

6 R. Soenarto Soerodibroto, KUHP dan KUHAP, Edisi Kelima, (Jakarta: PT. RajaGrafindo Persada, 2007), hal. 438. 
melakukan penistaan agama. Jaksa PN Medan sendiri mendakwakan Meliana dengan Pasal 156a KUHP tentang penistaan atau penodaan agama, khususnya agama Islam. ${ }^{7}$

Pasal 156a KUHP sebagai pasal penistaan atau penodaan agama dan bisa dikategorikan sebagai delik terhadap agama. Indonesia sendiri memiliki Undang-Undang No. 1/PNPS/1965 tentang Pencegahan Penyalahgunaan dan/atau Penodaan Agama yang selama ini dijadikan dasar hukum, selain KUHP, dan penindakan terhadap pelaku terkait sanksi hukum memuat rumusan sanksi pidana selama 5 tahun.

Berbicara mengenai volume adzan pada dasarnya Pemerintah telah melakukan aturan terkait penggunaan pengeras suara terkait dengan volume adzan di masjid, langgar dan mushola, aturan itu tertuang dalam Instruksi Direktur Jenderal Bimbingan Masyarakat Islam Nomor Kep/D/101/1978. Dan seiring dengan hal tersebut, Kementerian Agama juga telah mengeluarkan aturan tentang penggunaan pengeras suara di masjid yakni Surat Edaran Dirjen Bimas Islam No. B.3940/DJ.III/HK.00.07/08/2018 tanggal 24 Agustus 2018. ${ }^{8}$

Alasan Penulis mengangkat kasus Meliana di Tanjungbalai ini adalah didasarkan karena kasus ini mengusik sisi kemanusiaan dan rasa keadilan dalam masyarakat. Meskipun hal ini dibenarkan secara hukum, ketika Meliana dipanggil dengan emosinya ia memprotes vovolume suara adzan, di mana dalam hal itu unsur 156a KUHP terpenuhi dan Meliana divonis dengan hukum pidana penjara selama 18 bulan atau 1,5 tahun.

Berdasarkan uraian di atas, maka penulis tertarik untuk mengangkat kasus ini denagn judul: "Analisis Kebebasan Berpendapat Terhadap Agama Menurut Pasal 156a KUHP (Studi Kasus Putusan Nomor 784/Pid/2018/PT.Mdn)."

7 Anonim, "Banding Meiliana, yang divonis penjara 1,5 tahun karena keluhkan suara azan, ditolak Mahkamah Agung", https://www.bbc.com/indonesia/indonesia-47859654, diakses 8 September 2019.

${ }^{8}$ M. Syahran W. Lubis, "Penggunaan Pengeras Suara di Masjid, Ini Aturan Kemenag Sejak 1978", https://kabar24.bisnis.com/read/20180825/15/831383/penggunaan-pengeras-suara-dimasjid-ini-aturan-kemenag-sejak-1978, diakses 20 September 2019. 
Volume 2 Nomor 2, Desember 2019

\section{B. Perumusan Masalah}

Permasalahan yang dihadapi adalah bagaimana kebebasan berpendapat berkaitan agama menurut Pasal 156a KUHP (Studi Kasus Putusan Nomor 784/Pid/2018/PT.Mdn)?

\section{Metode Penelitian}

1. Tipe Penelitian

Tipe penelitian yang digunakan oleh Penulis adalah tipe penelitian hukum normatif. ${ }^{6)}$

2. Jenis dan Bahan Hukum

Pada penelitian ini, Penulis menggunakan jenis data sekunder. ${ }^{7)}$ Penelitian yang dilakukan berdasarkan bahan sekunder di mana datadata ini berasal dari bahan-bahan hukum seperti :

a. Bahan hukum primer terdiri dari perundang-undangan dan peraturan lain yang mengikat, antara lain: UUD 1945, KUHP dan Undang-Undang Nomor 8 Tahun 1981 tentang Kitab UndangUndang Hukum Acara Pidana (KUHAP).

b. Bahan hukum sekunder, terdiri dari pendapat atau doktrin para ahli, artikel-artikel, seminar-seminar, dan hasil-hasil karya ilmiah lainnya yang berhubungan dengan masalah perlindungan konsumen serta artikel dari internet.

c. Bahan hukum tersier, yang terdir dari kamus, ensiklopedia dan lain-lain.

Bahan-bahan nonhukum yaitu bahan-bahan penunjang di luar bahan hukum primer dan sekunder seperti kamus dan ensiklopedia serta petunjuk tambahan berupa wawancara dengan narasumber terkait.

3. Pendekatan

Penelitian hukum normatif mengenal beberapa pendekatanpendekatan yaitu antara lain: pendekatan UU (statute approach);

6) Peter Mahmud Marzuki, Penelitian Hukum Edisi Revisi, Cetakan ke-8, (Jakarta: Kencana Prenada Media Group, 2013), hal. 33.

7) Ibid., hal.181. 
pendekatan kasus (case approach); pendekatan sejarah (historical approach); pendekatan komparatif atau perbandingan (comparative approach); dan pendekatan konseptual (conseptual approach); ${ }^{8)}$

Pendekatan yang digunakan adalah pendekatan UU (statute approach) dan pendekatan kasus (case approach). Pendekatan undang-undang adalah pendekatan yang dilakukan dengan menelaah semua UU maupun regulasi yang berkaitan dengan kasus yang dibahas dan pendekatan kasus dilakukan dengan cara menelaah kasus-kasus terkait dengan isu yang sedang dihadapi. ${ }^{9)}$ Diantaranya terkait Pasal 156a KUHP dalam hubungannya dengan Putusan No. 784/Pid/2018/PT.Mdn.

4. Teknik Pengumpulan Bahan Hukum

Teknik pengumpulan bahan hukum yang digunakan adalah tinjauan pustaka atau (library research). Pengumpulan bahan hukum dari bahan hukum sekunder yang berasal dari artikel-artkel di internet dan wawancara kepada narasumber.

5. Teknik Pengolahan Bahan Hukum

Teknik pengolahan bahan hukum yang digunakan adalah pengolahan yang secara runtut dan sistematis sehingga memudahkan penulis melakukan analisis. Pengelolaan bahan hukum dilakukan secara sistematis, terarah dan terstruktur.

6. Teknik Analisis Bahan Hukum

Teknik analisis bahan hukum adalah dengan menggunakan metode analisis bahan hukum kualitatif, yaitu penelitian yang menekankan pada bahan-bahan hukum yang diperoleh dari berbagai sumber yang relevan.

\footnotetext{
8) Ibid., hal.93.

9) Ibid., hal. 135 .
} 
Volume 2 Nomor 2, Desember 2019

E-ISSN : 2655-7347

\section{PEMBAHASAN}

Sebelum membahas mengenai kebebasan berpendapat berkaitan agama menurut Pasal 156a KUHP (Studi Kasus Putusan Nomor 784/Pid/2018/PT.Mdn), Penulis terlebih dahulu menjelaskan mengenai dasar hukum terkait Pasal 29 ayat (2) UUD 1945. Oleh Karen aitu, Negara atau pemerintah berkewajiban memberikan perlindungan atau jaminan agar seluruh masyarakat yang berbeda keyakinan dapat menikmati kemajemukan dan kenyamanan dalam memeluk agama masing-masing dan mampu mengamalkannya sesuai ajarannya.

Selain menjamin kebebasan untuk memeluk agama, UUD 1945 juga menjamin mengenai kebebasan berpendapat dan berekspresi seperti tertera dalam Pasal 28, sedangkan hak berpendapat yang tercantum dalam Konvenan Hak Sipil dan Politik pada dasarnya sudah diratifikasi Indonesia melalui UU No 12 tahun 2005 Pengesahan International Covenant on Civil And Political Rights (ICCPR) atau Kovenan Internasional Tentang Hak-Hak Sipil dan Politik dalam Pasal 19 ayat (3), dimana ada pembatasan karena menyangkut kewajiban dan tanggungjawab khusus yang lebih spesifik dan tendensius.

Konteks kebebasan beragama yang dikaitkan dengan kebebasan menyuarakan pendapat bisa dilindungi adalah kebebasan perseorangan guna melaksanakan kepercayaannya, sehingga setiap hasutan untuk melakukan diskriminasi atas dasar agama harus dan wajib dilarang oleh hukum, demi kemajemukan dan kebhinekaan dalam memeluk agamanya masing-masing.

Dalam konteks perlindungan kebebasan beragama dijamin adanya kebebasan untuk menjalankan syariat agamanya, yaitu melalui pelarangan dalam bentuk hasutan atau dalam bentuk propaganda yang menghasilkan diskriminasi berdasarkan agama, bukan dalam konteks perlindungan institusi agama melalui tindak pidana penghinaan yang bersifat subjektif.

Tindak pidana terhadap agama pada dasarnya tidak dikenal dalam KUHP. Tindak pidana terhadap agama baru bisa dimasukkan dalam KUHP melalui UU No. 1/PNPS/1965 tentang Pencegahan Penyalahgunaan dan/atau Penodaan Agama dan dengan diakomodirnya "penodaan agama" dengan 
nama tindak pidana "penodaan", maka hakikat perlindungan kebebasan beragama menjadi kabur, pasal-pasal tentang penodaan agama tidak lagi mendukung perlindungan individu untuk melaksanakan kepercayaannya, namun digunakan untuk melindungi ajaran agama yang sifatnya dinamis dan subjektif, sehingga pada penerapan justru menyerang kelompok minoritas agama tertentu.

Salah satu aspek kemandirian dalam memeluk suatu agama adalah meurpakan pula suatu kemandirian bagi penegak hukum. Kemandirian epradilan mampu menciptakan kewajiban bagi hakim untuk tidak terpengaruh terhadap intimidasi atau desakan dari pihak lain, dan hakim harus mampu menunjukkan jatidiri sebagai penegak hukum yang taat pada etika profesi, dan semata-mata mendasarkan pada putusan hakim yang seadil-adilnya berdasarkan bukti awal yang cukup yang dihadirkan di persidangan.

Dengan kata lain penjelasan dari Pasal 156a KUHP memiliki persamaan dalam perbuatan lisan dan tulisan melalui perbuatan lain. Uraian lisan dan tertulis itu dari huruf a dimaksud adalah semata-mata ditujukan untuk niat tidak memusuhi dan menghina agama lain.

Dengan kata lain, dengan sengaja dalam konteks Pasal 156a huruf a KUHP, hanya ketika pelaku bertindak melampaui sekedar niatan dalam mengekspresikan perasaan keagamaan mereka dan ketika dengan niatan yang khusus/spesifik atau dengan tujuan untuk menghina agama lainnya melalui ekspresi permusuhan secara langsung, sehingga kemudian hukum dapat mengintervensi dan menentukan garis batas antara keyakinan dan ekspresi yang dilindungi atau tidak dilindungi.

Terkait dengan unsur "dengan sengaja" adalah merupakan unsur yang mewakili mens rea/niat jahat, sehingga unsur ini dapat terpenuhi, maka pelaku haruslah terbukti menghendaki agar adanya permusuhan, penodaan terhadap suatu agama yang dianut di Indonesia, sebagaimana dimaksud dalam unsur Pasal 156a huruf a KUHP.

Pada kasus Meliana, JPU dan Hakim PN Medan membuktikan dan menyatakan unsur "dengan sengaja" terpenuhi dengan pertimbangan fakta 
bahwa Meliana telah tinggal di daerah tersebut selama 8 tahun, di mana rumahnya hanya berjarak 10 meter dari masjid. Dari beberapa masyarakat sekitar di lingkungan Masjid Al Maksum, terdakwa mengeluhkan volume adzan yang keras, keluhan itu disampaikan pada jam 7 pagi, yang secara umum dipastikan jam segitu tidak ada kumandang suara adzan dari masjid Al Maksum Tanjungbalai.

Selain itu, JPU dan Hakim PN Medan juga mempertimbangkan saksi lian yaitu Kasini alias Ka UO dan bukan kepada orang lain jika ingin menyampaikan pendapat terkait keluhan suara adzan dari Masjid Al Maksum. Dalam hal ini, JPU dan Hakim PN juga mempertimbangkan ada unsur sengaja mengingat mendatangi di warung (sebagai tempat umum) memiliki konotasi bahwa maksud terdakwa agar umum mengetahui maksud terdakwa atas ketidaknyaman terhadap volume suara adzan, disisi lain, terdakwa juga menghendaki dikecilkannya volume adzan, ini tentunya berakibat terhadap jamaah yang ingin sholat ketika waktu sholat menjadi tidak bisa mendengar dan akhirnya tidak bisa melaksanakan sholat secara berjamaah, dan ini tentunya akan menimbulkan kemarahan bagi umat Islam secara keseluruhan di Medan, dan khususnya di Tanjungbalai.

Hal senada juga disampaikan Dr. Hendra, S.H., S.E., M.M., M.H., selaku akademisi dari Universitas Krisnadwipayana, Beliau berpendapat bahwa unsur 156a KUHP terpenuhi dan hal ini sejalan dengan pendapat hakim terkait permintaan suara adzan yang bila dikecilkan volume tentunya jamaah tidak mendengar, dan adzan itu yang dikumandangkan di Masjid adalah syariat agama Islam yang dikumandangkan sebagai tanda masuk waktu Shalat dan atau menyuruh umat Islam untuk melaksanakan sholat. Di tambah lagi, ketika Meliana disamperin warga, sikap Meliana malah ngotot dan ini tentunya mengandung kebencian di muka umum, sehingga hal tersebut memenuhi unsur 156a KUHP dan hal tersebut masuk kategori penistaan / penodaan agama terhadap kegiatan sholat berjamaah atau ibadah umat Islam di Masjid Al-Maksum, Tanjungbalai. 
Volume 2 Nomor 2, Desember 2019

E-ISSN : 2655-7347

Menurut pendapat Penulis kebebasan berpendapat itu bukanlah merupakan kebebasan yang sebebas-bebasnya, tapi kebebasan yang dibatasi oleh peraturan yang berlaku (UU). Kasus ini menurut penulis berbau ketidaksenangan terhadap umat Islam dalam menjalankan ibadah, tentunya perlu dilakukan antisipasi atau pencegahan.

Di sisi lain, penulis juga berpendapat bahwa percakapan antara Meliana dan Saksi Kasini alias Kak UO tidak dapat dikategorikan sebagai tindakan yang memenuhi unsur "dengan sengaja”. Hal ini dikarenakan unsur "dengan sengaja" berarti menghendaki mewujudkan perbuatan sadar da mengetahui akibat yang ditimbulkannya. Berdasarkan keterangan yang diperoleh, Meliana tidak menghendaki akibat atas ucapannya yaitu pengrusakan rumahnya sendiri ataupun pembakaran vihara-vihara yang ada di Kota Tanjungbalai. Bahwa berdasarkan keterangan Meliana, dirinya mengatakan bahwa "kok besar kali suara di Masjid itu, dulu ga begitu" sedangkan berdasarkan keterangan saksi Kasini alias Kak UO, "kak tolong bilang sama uak itu, kecilkan suara masjid itu kak, sakit kupingku, ribut". Bahwa dari rangkaian fakta dan keterangan saksi terlihat bahwa tidak ada niat dari Saudari Meliana untuk memunculkan rasa kebencian terhadap umat Islam khususnya di Tanjungbalai.

Sangat penting untuk melihat bahwa apakah permintaan tolong mengecilkan suara adzan masjid termasuk dalam kategori perbuatan yang memiliki sifat permusuhan dan penodaan agama? Terkait dengan unsur "bersifat permusuhan" diperlukan keterangan, salah satunya dari ahli psikologis guna membuktikan bahwa dalam diri kejiwaan Meliana sudah terdapat sifat permusuhan atau rasa kebencian terhadap suatu agama yang dianut di Indonesia.

Terkait unsur "penistaan atau penodaan agama", maka hal tersebut dibutuhkan peranan dan saksi ahli guna membantu para penegak hukum apakah itu masuk kategori perbuatan yang mengandung permusuhan atua penodaan terhadap suatu agama. Keterangan ahli biasanya disampaikan menurut pengetahuan sehingga keterangan ahli itu bisa saling melengkapi dan 
menjadi bukti di persidangan. Seorang ahli dalam bidang yang dihadirkan di pengadilan biasanya memiliki kompeten terkait ilmu hukum yang dimiliki untuk menyampaikan atau memberikan pandangannya terhadap suatu kasus dilihat dari sudut hukum sesuai aturan perundangan yang berlaku. Mengingat dalam hukum ada istilah dissenting opinion atau perbedaan pendapat, dan ini lazim terjadi di sidang pengadilan terkait peran hakim dalam memutus suatu perkara.

Menurut pendapat Penulis, JPU dan Hakim PN Medan dalam kasus Meliana ini mengesampingkan fakta bahwa telah terjadi pengrusakan rumah dengan pelemparan oleh massa terhadap rumah Meliana, di mana Meliana pada dasarnya juga menyadari bahwa hal ini akan menimbulkan kemarahan besar bagi umat Islam di Medang, khususnya di Tanjungbalai. Selain itu terdapat fakta di lapangan sebagaimana yang diungkapkan oleh saksi Alrivai Zuherisa alias Aldo dan saksi Budi Ariyanto bahwa mereka mengetahui adanya pelarangan adzan yang dilakukan oleh Meliana adalah dari isu yang berkembang di masyarakat sekitar masjid Al-Maksum Kota Tanjungbalai yang tidak diketahui dan tidak dikenal siapa masyarakat yang menyebarkan isu pelarangan adzan tersebut. Selain itu, JPU dan Hakim PN Medan dalam kasus ini juga tidak mempertimbangkan bahwa Meliana-lah yang terancam dan akan diusir oleh pihak Saksi-saksi yang hadir ke rumahnya. Selain itu, berdasarkan fakta, saat proses mediasi dan klarifikasi berlangsung di kelurahan, justru suaminyalah yang mendapatkan ancaman pemukulan dari seorang laki-laki yang tidak dikenal.

Selain itu, JPU dan hakim PN tidak mempertimbangkan adanya upaya pihak Meliana untuk melakukan klarifikasi, misalnya dengan melakukan permintaan maaf dari suaminya. Seharusnya permintaan maaf ini dapat dilihat sebagai fakta hukum untuk menggagalkan terbuktinya unsur niat, bahwa tidak ada kesengajaan untuk melakukan permusuhan atau penodaan agama. Penjelasan pasal 4 UU PNPS/156a adalah terkait hubungannya dengan pernyataan Meliana yang dapat dilihat sebagai pernyataan yang "obyektif" 
atau situasi tertentu dan "menghindari kata-kata yang bersifat permusuhan" sehingga perbuatan ini bukan tindak pidana menurut Pasal 156a KUHP.

Berdasarkan penjelasan di atas, perbuatan Meliana juga harus dibuktikan secara jelas dan dicermati secara seksama mengenai unsur terpenting dalam Pasal 156a KUHP adalah "yang pada pokoknya bersifat permusuhan, penyalahgunaan atau penodaan terhadap suatu agama yang dianut di Indonesia."

Di sisi lain, hakim berpendapat bahwa Pasal 156 KUHP jo Pasal 156a KUHP tidak bisa dimasukkan dalam suatu kelompok tindak pidana penghinaan, oleh sebab itu makna penodaan itu sendiri mengandung sifat penghinaan terhadap agama yang bersangkutan. Dan tidak mengandung unsur penodaan terhadap agama.

Jika dikaitkan pula dengan dakwaan subsider terhadap Meliana, yaitu pasal $156 \mathrm{KUHP}$, maka berdasarkan fakta di atas, terkait dengan unsur-unsur yang ada dalam pasal 156 KUHP tersebut tidak terpenuhi oleh tindakan yang dilakukan oleh Meliana. Unsur perasaan permusuhan, kebencian atau penghinaan tidak dapat dibuktikan oleh JPU sebagaimana JPU tidak dapat membuktikan unsur yang pada pokoknya bersifat permusuhan, penyalahgunaan atau penodaan terhadap suatu agama yang dianut di Indonesia dalam dakwaan primairnya.

Berdasarkan fakta diatas, Meliana dalam kasus ini justru merupakan korban akibat tindak pidana pengrusakan terhadap rumahnya yang dilakukan oleh massa yang meluapkan marah dan emosinya saat itu dikarenakan informasi yang tidak akurat. Meliana termasuk kelompok rentan sebagai perempuan. Apa yang dilakukan oleh terdakwa hanyalah sebuah permintaan tolong untuk mengecilkan suara speaker/toa/pengeras suara untuk mengumandangkan adzan di masjid.

Ini artinya bahwa Meliana sebagai warga Negara tetap berhak mendapat pengakuan, jaminan dan perlindungan hukum serta kepastian yang adil dan harus diperlakukan sama di muka persidangan sesuai Pasal 28D ayat (1) UUD 1945. Di sisi yang lain, Meliana juga merupakan seorang perempuan yang 
wajib mendapatkan perlindungan dari tindakan ataupun penghukuman yang diskriminatif serta dirinya adalah seorang ibu yang mempunyai kewajiban mengurus keempat anaknya. Di ruang pubik, Meliana mungkin dianggap menyinggung perasaan keagamaan sebagian pihak, tetapi secara hukum tidak mencukupi untuk dianggap bersalah apalagi menerima hukuman penjara. Untuk itulah peran pengadilan, dimana untuk menegakkan hukum dan perlindungan warga negara dari kesewenang-wenangan, atau "memfasilitasi" kehendak mayoritas.

Berdasarkan uraian tersebut di atas, Penulis berpendapat bahwa kasus yang penulis kaji ini adalah masuk dalam kategori konflik etno religious yang apda dasarnya dipicu oleh ketersinggungan atas pernyataan Meliana, seorang warga keturunan Tionghoa yang dianggap sebagian warga di Tanjungbalai sebagai bentuk penghinaan atau penodaan terhadap salah satu agama yaitu agama Islam. Pada dasarnya, Meliana tidak menyangka bahwa akibat dirinya mengeluhkan volume adzan menimbulkan konflik dan berbuah menjadi petaka bagi Meliana. Tentunya Meliana menghargai umat lain beribadah, dan perlu diketahui Meliana sudah tinggi di Tanjungbalai di wilayah Masjid Al Maksum ini hamper sudah 8 tahun.

Kasus penodaan agama yang dituduhkan ke Meliana cukup menarik untuk dibahas dan dianalisis, dan sebenarnya tidak ada masyarakat yang melaporkan kasus ini kepolisian. Polisi hanya mengetahui adanya keributan yang berujung konflik. MUI Kota Tanjungbalai pada dasarnya tidak mau mengeluarkan fatwa, mengingat adanya desakan dari ormas seperti FUI, HTI, Alwasliyah, dan ormas lain mendesak AMMIB untuk mengelar dan menyegel kantor MUI Tanjungbalai bilamana tidak mengeluarkan fatwa MUI. Mengingat ini sudah merupakan bentuk penistaan atau penodaan agama menurut mereka, dan menurut penafsiran mereka, Meliana memaknai masjid sebagai tempat biang rebut atau kebisingan.

Dan ini diamini oleh masa, dan Meliana dituduh telah melakukan penodaan atau penistaan agama berdasarkan Pasal 156a KUHP. Polisi pada dasarnya sulit membangun kasus ini agar terang benderang, sebenarnya ada 3 
saksi kunci, namun mereka berbeda-beda dalam menyampaikan kesaksian terhadap kasus ini.

Pada dasarnya bukti lain yang menjerat Meliana adalah adanya surat pernyataan yang ditandatangani oleh 100 orang dari anggota BKM Al Maksum dan Fatwa MUI Sumatera Utara, yang menyatakan bahwa Meliana melakukan pelanggaran dan melakukan penodaan agama. JPU pada dasarnya hanya mengacu pada fatwa MUI. Katanya menurut saksi ada rekaman dan sudah diberikan ke Hakim, namun dalam hal ini hakim tidak pernah menghadirkan barang bukti yang dimaksud di muka persidangan.

Di sisi lain, Penulis juga beranggapan bahwa kerusakan terhadap rumah Meliana dan tempat ibadah di Tanjungbalai itu pada dasarnya merupakan aksi spontan kemarahan umat Islam terhadap Meliana yang menurut massa melakukan penodaan agama, sehingga menimbulkan kemarahan yang meluas se Tanjungbalai.

Disisi lain, adanya mobilisasi massa ini pada dasarnya akibat kemarahan masyarakat atas ketersinggungannya terhadap ucapan Meliana yang menurut dia masuk dalam kategori penodaan agama. Dan hal mendasar tentunya adanya miskomunikasi, sehingga konflik meluas. Di sisi lain adanya pemberitaan media cetak dan elektronik dimana Meliana adalah sang pemicu kerusahan akibat melakukan penodaan terhadap agama Islam.

Hal yang perlu ditekankan Penulis di sini adalah terkait adanya unsur Pasal 156a KUHP yang septutnya tidak sudah digunakan lagi. Cara terbaik menyikapi permasalahan ini adalah melakukan dialog guna menemukan titik temu, win win solution, peran pemuka agama sangat dominan dalam menyelesaikan kasus ini.

Banyak pihak menyanyangkan vonis yang diterima Meliana, rasa keadilan yang terkoyak, dan vonis ini tentunya menguatkan sinyalemen pendapat awam bahwa kasus ini digiring dan sifatnya menyudutkan, disisi lain kurangnya pemahaman hakim menyikapi dan memutus kasus ini. Di sisi lain juga adanya UU PNPS 1965 terkait penodaan agama, yang menurut penulis sarat akan terjadinya pelanggaran HAM. 
Kasus Meliana ini menimbulkan dilemma terkait kemajukan beragama di Indonesia pada umum, khususnya di Tanjungbalai, diantaranya adalah tidak adanya aturan baku atau payung hukum mengenai volume adzan di mushola, langgar dan masjid. Kementerian Agama RI pada dasarnya telah mengeluarkan peraturan berupa intruksi Dierektur Jendral Bimbingan Masyarakat Islam Nomor KEP/D/101/1978 tentang Tuntunan Penggunaan Pengeras Suara di Masjid dan Musala. Sayangnya aturan dan regulasi ini tidak mengatur secara jelas volume suara adzan di masjid.

Kasus Meliana ini tentunya menjadi pembelajaran bagi kita semua, untuk saling menghargai, menghormati, toleransi antar umat beragama. Masyarakat harus dewasa, jangan mudah terprovokasi oleh hasutan orang lain untuk melakukan perusakan akibat gesekan yang mengandung unsur agama, sehingga menimbulkan kerugian yang besar bagi masyarakat dan juga menimbulkan ketidakharmonisan dalam bertoleransi antar umat beragama.

Menurut penulis Pasal 156a dalam KUHP merupakan pasal karet, dan sering menimbulkan gesekan antar umat beragama, dan melanggar HAM dalam hubungannya dengan kebebasan individu, khususnya dalam penafsiran keyakinan. Dan menurut penulis padal 156a KUHP sebagai pasal penodaan agama adalah bermasalah dan tidak usah dipakai lagi dalam implementasi atau penerapannya. Alasannya karena tidak bisa diukur, hukum dan kejahatan sendiri bisa diukur, dan ini jelas sebagai pasal karet.

Hal terpenting, tentunya harus ada upaya guna memperbaiki sebagaimana otoritas keagamaan mana yang boleh menyatakan suatu pernyataan atau perlakuan yang dianggap sebagai bentuk penodaan agama.

Untuk itu ada beberapa hal bisa dijadikan acuan menurut Penulis dan bisa dijadikan pegangan dalam mengatasi kasus ini :

1. Mengedepankan hak-hak orang lain. Menjaga hak orang lain adalah kewajiban. Itu diatur oleh hukum negara juga hukum dan norma semua agama. Dalam Islam, mengumandangkan adzan itu hukumnya sunnah sedangkan menghormati tetangga (orang yang ada di sekitar kita) adalah 
wajib. Apa mungkin kita mengedepankan dan mendahulukan perbuatan sunnah dengan mengabaikan kewajiban?

2. Tak menggunakan cara kekerasan. Perbedaan atau perselisihan yang terjadi di tengah masyarakat tidak boleh menggunakan kekerasan berupa intimidasi atau lainnya dalam menyelesaikannya. Menggunakan musyawarah dengan pendekatan kekeluargaan dipandang lebih elok dan bijak. Sebab kekerasan akan mendatangkan mudharat yang lebih besar. Kekerasan tak akan menyelesaikan masalah. Kekerasan hanya akan memperluas konflik saja.

3. Menjujung tinggi toleransi dalam beragama. Indonesia adalah negara majemuk. Itu fakta. Kemajemukan tersebut adalah kekayaan Indonesia. Maka kemajemukan dengan segala perbedaan yang menyertainya kudu dijaga. Soal perbedaan agama, toleransi merupakan solusinya.

4. Ke depannya, kontroversi tentang Pasal 156a KUHP segera diselesaikan. Pilihanya tak lain kecuali menghapus pasal karet yang telah banyak memakan korban tersebut. Pemerintah dan DPR RI secepatnya bertindak dengan menghapus Pasal itu. Pasal Pasal 156a KUHP terbukti terus memakan korban. Laporan kemerdekaan beragama atau berkeyakinan dan politisasi agama tahun 2017 yang dikeluarkan oleh Wahid Foundation saja mencatat telah terjadi 18 tindakan kriminalisasi berdasarkan agama atau keyakinan oleh negara dan 10 tindakan oleh non-negara.

5. Penegakan hukum harus adil. Hukum tak boleh diintervensi oleh siapapun. Pengambilan keputusan hukum oleh penegak hukum berdasarkan pada fakta bukan pada tekanan massa misalnya. Hukum itu selayaknya mencerminkan suara Tuhan. Artinya tak boleh salah. Apalagi asal. Ini menjadi tanggungjawab semua penegak hukum. Kasus Meliana adalah pelajaran bagi semua bahwa saling menghormati dan menjaga hak orang lain itu penting. Perbedaan dalam beragama harus disikapi dengan toleransi. Hukum harus ditegakan demi keadilan. Dan saatnya, Pasal 156a KUHP tentang penodaan agama dihapus guna kebaikan kehidupan bermasyarakat di masa mendatang. 


\section{PENUTUP}

\section{A. Kesimpulan}

Berdasarkan uraian dari bab-bab sebelumnya, dapat ditarik kesimpulan bahwa Terdakwa Meliana dalam perkara Putusan Nomor 784/Pid/2018/PT.Mdn. divonis dengan pidana penjara selama satu tahun enam bulan atau 1,5 tahun. Di mana terdakwa didakwa melakukan penodaan agama dan terpenuhinya rumusan Pasal 156a KUHP terkait penodaan agama, di mana terdakwa mengeluhkan suara adzan di Masjid Al-Maksum Tanjung Balai. Kasus ini pada dasarnya harus disikapi dengan jernih dengan mengedepankan pada kesetaraan yang sama di muka hukum dan tak terkalah penting adalah menjunjung tinggi kebhinekaan dalam beragama, saling menghargai agama lain, tidak terprovokasi, terintimidasi oleh sekelompok orang dan tidak adanya penggiringan opini terhadap penodaan agama. Dan terpenting dalam menyuarakan pendapat dan keluhan, tentunya harus bisa menyuarakan pendapat sebebas-bebasnya, namun harus mengacu pada aturan, hukum yang berlaku.

\section{B. Saran}

Saran yang bisa penulis sampaikan dalam penulisan skripsi ini adalah perlunya kehadiran pemerintah dalam menyikap permasalahan ini yaitu dengan merevisi UU No. 1/PNPS/1965, agar UU tersebut bisa mengakomodir banyak kepentingan. Dalam hal ini, sebagai WNI, Meliana sebagai kalangan minoritas yang sangat rawan intimidasi dan diskriminasi diberi pemahaman agar tidak melakukan tindakan yang menimbulkan gesekan, mengingat urusan agama sarat terjadinya konflik. Dan penegak hukum sendiri harus jeli menyikapi permasalahan ini. Penanganan kasus penodaan agama harus dilakukan secara hati-hati selalu berpegang teguh terhadap mekanisme yang ada, dan terpenting aparat penegak hukum memahami esensi UU penodaan agama agar tidak menjadi preseden buruk di tengah masyarakat, khususnya masyarakat muslim Indonesia. 


\section{DAFTAR PUSTAKA}

\section{A. Buku}

Budiardjo, Miriam. Dasar-dasar Ilmu Politik. (Jakarta: PT. Gramedia, 2008).

Majda, El Muhtaj. Hak Asasi Manusia dalam Konstitusi Indonesia. (Jakarta: Kencana, 2007).

Marzuki, Peter Mahmud. Penelitian Hukum Edisi Revisi. Cetakan ke-8. (Jakarta: Kencana Prenada Media Group, 2013).

Soerodibroto, R. Soenarto. KUHP dan KUHAP. Edisi Kelima. (Jakarta: PT. RajaGrafindo Persada, 2007).

\section{B. Jurnal}

MS, Afriandi. "Analisis Hukum Pidana Terhadap Tindak Pidana Penistaan Agama di Aceh". Jurnal Penelitian Hukum DE JURE, ISSN 1410-5632 Vol. 17 No. 1, Maret 2017: 1- 12.

\section{Website}

Anonim. "Banding Meiliana, yang divonis penjara 1,5 tahun karena keluhkan suara azan, ditolak Mahkamah Agung”, https://www.bbc.com/indonesia/indonesia-47859654, diakses 8 September 2019.

Lubis, M. Syahran W. "Penggunaan Pengeras Suara di Masjid, Ini Aturan Kemenag Sejak 1978". https://kabar24.bisnis.com/read/20180825/15/831383/penggunaanpengeras-suara-di-masjid-ini-aturan-kemenag-sejak-1978, diakses 20 September 2019.

Shidarta. "Bahaya Tafsir A-Historis Terhadap Pasal 156a KUHP". https://business-law.binus.ac.id/2018/07/10/bahaya-tafsir-a-historisterhadap-pasal-156a-kuhp/, diakses 20 September 2019. 